\title{
Chlorophyll indexes and gas exchanges of Talisia esculenta seedlings in organic substrates and biofertilizer
}

Índices clorofiláticos e trocas gasosas em mudas de Talisia esculenta com substratos orgânicos e biofertilizante

\author{
A. G. Cavalcante ${ }^{1 *}$; A. C. P. Cavalcante ${ }^{2}$; J. da S. Henrique ${ }^{3}$; M. M. M. Dantas ${ }^{3}$; \\ J. F. C. Zuza ; R. da C Araújo ${ }^{3}$ \\ ${ }^{1}$ Universidade Estadual Paulista "Júlio de Mesquita Filho", 14884-900, Jaboticabal - SP, Brazil \\ ${ }^{2}$ Universidade Federal de Viçosa, 36570-900, Viçosa-MG, Brazil \\ ${ }^{3}$ Universidade Federal da Paraíba, 58220-000, Bananeiras - PB, Brazil \\ ${ }^{4}$ Universidade Federal de Santa Maria, 97105-900, Santa Maria-RS, Brazil \\ *adailzacavalcante@gmail.com
}

(Recebido em 19 de dezembro de 2019; aceito em 27 de maio de 2020)

\begin{abstract}
The Talisia esculenta (popularly called Talisia esculenta) is a native plant from Brazil with great socioeconomic importance regarding its extraction cultivation, however only a few scientific studies were carried out with this species, especially concerning its physiological characteristics. The aim of the present study was to evaluate the utilization of different organic substrates and biofertilizers through the soil on the physiological performance of T. esculenta seedlings. The experiment was performed between August and November 2015. The trial design consisted of randomized blocks, with a factorial arrangement $4 \times 2$ corresponding to four substrates (Test: control group; SE: commercial substrate; RFV: compost of fruit and vegetable remains; RPI: substrate with remains of industrialized food), in both presence and absence of biofertilizer, with five replicates. The analyzed variables were chlorophyll indexes $a, b$ and gas exchanges. The chlorophyll rates $a, b$ and total were higher on SE, RFV and RPI, but no influences of the biofertilizer were detected on the chlorophyll indexes of $T$. esculenta seedlings. All substrates (SE, RFV and RPI) increased the chlorophyll indexes $a, b$ and total of the seedlings. The substrates increases the chlorophyll a, $\mathrm{b}$ and total indices, except for the control substrate independent of the application of biofertilizer. The efficiency of gas exchange increases with the addition of biofertilizer.

Keywords: plant physiology, Talisia esculenta, organic wastes.
\end{abstract}

A Talisia esculenta é uma planta nativa do Brasil com grande importância socioeconômica para o extrativismo, porém ainda não existem relatos sob as características fisiológicas desta espécie. Devido à falta de estudos sobre a Talisia esculenta, o objetivo da pesquisa foi avaliar a utilização de diferentes substratos orgânicos e aplicação de biofertilizante via solo sobre o índice de clorofila e as trocas gasosas na fase de muda da espécie. $\mathrm{O}$ experimento foi realizado entre os meses de agosto a novembro de 2015. O delineamento experimental utilizado foi em blocos casualisados, com arranjo fatorial de $4 \times 2$ correspondente a quatro substratos (TES=testemunha; $\mathrm{SE}=\mathrm{Composto}$ de restos de frutas e legumes da Empresa Paraibana de Abastecimento e Serviços Agrícolas; RFV= composto de restos de frutas e verduras; RPI=substrato com restos de comida industrializada) com presença e ausência de biofertilizante em cinco repetições. As variáveis analisadas foram índices de clorofila $\mathrm{a}, \mathrm{b}$, total e trocas gasosas. Os índices de clorofila a, b e total nas mudas de T. esculenta foram aumentados nos substratos RFV (composto de restos de frutas e verduras) e RPI (substrato com restos de comida industrializada), porem a adição de biofertilizante não influenciou nos índices clorofiláticos. Os substratos aumentam os índices de clorofila a, b e total, exceto o substrato controle, independente da aplicação do biofertilizante. A eficiência das trocas gasosas aumenta com a adição de biofertilizante.

Palavras-chave: Fisiologia vegetal, Talisia esculenta, resíduos orgânicos.

\section{INTRODUCTION}

Talisia esculenta Raldk are widespread in Brazil, found especially in the states of Amazonas, Pará, Bahia, Ceará, Maranhão, Pernambuco, Piauí, Goiás, Mato Grosso, Mato Grosso do Sul, Minas Gerais, Rio de Janeiro, São Paulo, and Paraná [1]. Brazil is widely covered by native forests 
with an enormous diversity of little studied fruit trees, many of them with a great potential of commercial use [2]. In this context, T. esculenta trees are of great ecological, economic and medicinal interests, being indicated for the recovery of riparian forests, as well as in natura consumption and the production of jams, jelly and candies with high vitamin contents [3].

According to Wetzel et al. (2011) [4], native plants vary in terms of soil fertility demands, but most of the species respond favorably to fertilization with organic matter. Fertilization with organic fertilizers has been widely used due to its capacity of providing variable quantities of different nutrients, especially nitrogen, phosphorus and potassium. Additionally, these are highly efficient in providing increased water retention conditions of soils and an adequate nutritional quality to different cultures [5].

The choice of substrate must be made taking into account the physical and chemical characteristics required by the species and economic aspects, because, in addition to providing adequate growth to the plant, the material used in the composition of the substrate must be abundant in the region and have a low cost [6]. As an alternative to organic fertilizers, waste generated in the agribusiness has been highlighted [7]. In which it has gained prominence for providing varying amounts of nutrients, especially nitrogen, phosphorus and potassium, in addition, they are quite efficient in providing conditions of high moisture retention in the soil and adequate nutritional quality in different cultures $[6,8]$.

Regarding production itself, every crop is dependent of its photosynthetic capacity, as well as how plants allocate carbohydrates to their growth and development [9]. The balance between respiration and photosynthesis displays a direct influence on the plant's yield. However, there is limited data regarding the possibilities that affects the carbon balance in tropical plants [10]. Despite its socioeconomic importance derived from extraction cultures, Talisia esculenta tree is little studied and yet there is no relates concerning its physiological characteristic. Thus, the aim of this study was to evaluate the use of different organic substrates and the application of biofertilizer through soil on the physiological performance of T. esculenta seedlings.

\section{MATERIAL AND METHODS}

The experiment was performed in August to November 2015 in a greenhouse of the Center of Human, Social and Agrarian Sciences (CCHSA) of the Federal University of Paraíba (UFPB), Bananeiras-PB. The experimental design consisted of randomized blocks with a factorial arrangement of $4 \times 2$, corresponding to four substrates (Test: control; SE: commercial compost of the Company of Supply and Agricultural Services of Paraíba; RFV: compost made with fruits and vegetables remains from the university restaurant and RPI: substrate with food remains from the same restaurant), and two (without the presence of a biofertilizer), with five repetitions.

For substrate composition, the used soil was a Dystrophic Yellow Latosol, classified as the criteria of the Brazilian Soil Classification System SiBCS [11], sampled at $20 \mathrm{~cm}$ depth on the Agriculture Sector of CCHSA-UFPB. The commercial substrate (SE) is derived from aerobic composting of fruits and vegetable remains disposed by traders. Regarding the composts made with fruits, vegetable and food remains (RFV) obtained in the university restaurant of CCHSAUFPB, these were prepared during 90 days with the addition of bovine manure. Compost piles were $1.5 \mathrm{~m}$ wide and $1.20 \mathrm{~m}$ height.

The "supermagro" biofertilizer was produced according to Penteado (2007) [12] and its application was performed every fifteen days after the emergence of plants, in the concentration of $5 \%$. Data regarding the chemical analysis performed to analyze the fertility potential of both the compounds and biofertilizer is shown in Table 1.

Seeds were collected from mother-plants in the Municipality of Remígio - PB, and disposed to germinate in plastic bags $(18 \mathrm{~cm} \mathrm{x} 30 \mathrm{~cm})$, on the proportion of 2:1 (v/v), i.e. two parts of soil for one part of compost. 90 days after emergence (DAE), when plants were ready to be taken to cropping fields, the chlorophyll indexes $a, b$ and total were performed, as well as the gas exchange analysis. For the analysis of chlorophyll indexes, a portable chlorophyll-meter ClorofiLOG CFL1030 was used, with readings performed in three leaves exposed to solar radiation (from top to base, being the third and fourth photosynthetic active leaves). 
Table 1. Chemical analysis regarding the fertility potential of organic composts and biofertilizer.

\begin{tabular}{|c|c|c|c|c|c|c|c|c|c|c|c|c|c|}
\hline Sample & $\begin{array}{c}\mathrm{PH} \\
\mathrm{H}_{2} \mathrm{O} \\
(1: 2,5)\end{array}$ & $\mathrm{P}$ & $\mathrm{K}^{+}$ & $\mathrm{Na}^{+}$ & $\begin{array}{l}\mathrm{H}^{+}+ \\
\mathrm{Al}^{+3}\end{array}$ & $\mathrm{Al}^{+3}$ & $\mathrm{Ca}^{+2}$ & $\mathrm{Mg}^{+2}$ & SB & CEC & V & M & O.M. \\
\hline & & \multicolumn{2}{|c|}{$\mathrm{mg} / \mathrm{dm}^{3}$} & \multicolumn{7}{|c|}{. } & \multicolumn{2}{|c|}{$---\%---$} & $\mathrm{g} / \mathrm{kg}$ \\
\hline Test & 5,42 & 8,68 & 60,00 & 0,17 & 2,15 & 0,05 & 1,50 & 1,30 & 3,13 & 5,27 & 59,32 & 1,57 & 5,68 \\
\hline SE & 7,20 & 230,21 & 980,50 & 1,80 & 3,51 & 0,00 & 7,75 & 1,95 & 14,01 & 17,52 & 79,96 & 0,00 & 86,90 \\
\hline RFV & 7,07 & 301,39 & 4500,00 & 2,00 & 3,96 & 0,00 & 12,40 & 2,90 & 28,81 & 32,77 & 87,92 & 0,00 & 103,96 \\
\hline RPI & 6,00 & 305,21 & 3800,00 & 6,96 & 7,75 & 0,40 & 8,50 & 4,20 & 29,38 & 37,13 & 79,11 & 1,34 & 119,58 \\
\hline
\end{tabular}

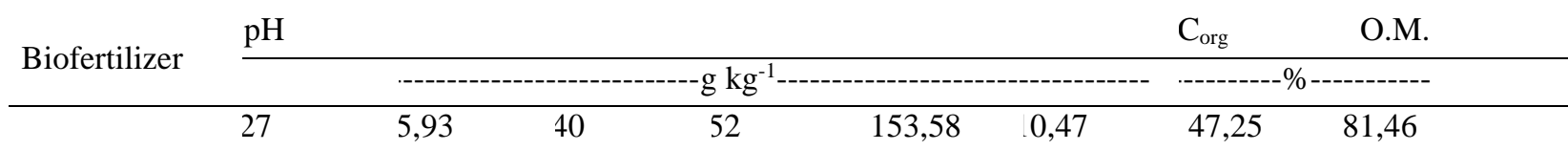

* $C_{\text {org }}$ : organic carbon; O.M.: organic matter. (Test: control; $S E$ : compost made with fruits and vegetables remains of the company; RFV: compost made with fruits and vegetables remains from the University restaurant of CCHSA-UFPB; RPI: substrate with food remains.

The analyzed gas exchange characteristics were respiratory and photosynthetic rate, internal concentration of $\mathrm{CO}_{2}$, stomatal conductance, water efficiency use and instantaneous carboxylation efficiency. These analyzes were carried out with the aid of an open-system photosynthesis equipment with a $\mathrm{CO}_{2}$ analyzer and water vapor by infrared radiation (Infra Red Gas Analyzer - IRGA, model LI-6400, Li-Cor ${ }^{\circledR}$ ), with the temperature control set at $25^{\circ} \mathrm{C}$, irradiation of $1800 \mu$ mol.photon. $\mathrm{m}^{-2} \cdot \mathrm{s}^{-1}$ and air flux of $200 \mathrm{~mL} \cdot \mathrm{min}^{-1}$. These measurements were performed from $08 \mathrm{~h} 00$ to $10 \mathrm{~h} 00$.

The water use efficiency (WUE) was determined against the relation of $\mathrm{CO}_{2}$ assimilation and transpiration index $(\mathrm{A} / \mathrm{E})$. The carboxylation efficiency $(\mathrm{A} / \mathrm{Ci})$ was determined through the relation between $\mathrm{CO}_{2}$ assimilation rate and leaf internal $\mathrm{CO}_{2}$ concentration. The data were submitted to analysis of variance by the F test and the means grouped by the Scott-Knott test (P $<0.05)$. The analyzes of variance using the software ASSISTAT, version 7.7 beta [11].

\section{RESULTS AND DISCUSSION}

The chlorophyll indexes were higher on the SE, RPI and RFV in 10, 17 and $14 \%$ respectively for chlorophyll $a, 22,32$ and 32\% for chlorophyll $b$ and 9, 17 and 15\% for total chlorophyll, when compared to the control treatment (Figures 1A, 1C and 1E). The biofertilizers application had no influence on seedlings' chlorophyll index. (Figures 1B, 1D and 1F).

These indices are used to estimate the photosynthetic potential of plants, by the direct connection with the absorption and transfer of light energy, thus being one of the hypotheses that plants with a high concentration of chlorophyll would be able to achieve higher photosynthetic rates and thus increase in plant growth [13]. Chlorophylls are related both to the plants' photosynthetic efficiencies and its growth [14], being constituted by magnesium and nitrogen in its cyclic portion. In SE, RFV and RPI substrates, the observed high rates of these nutrients may have contributed to such results. 
A

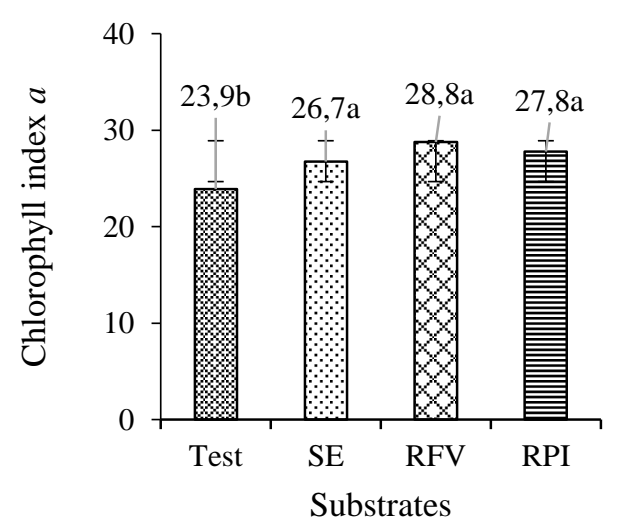

C
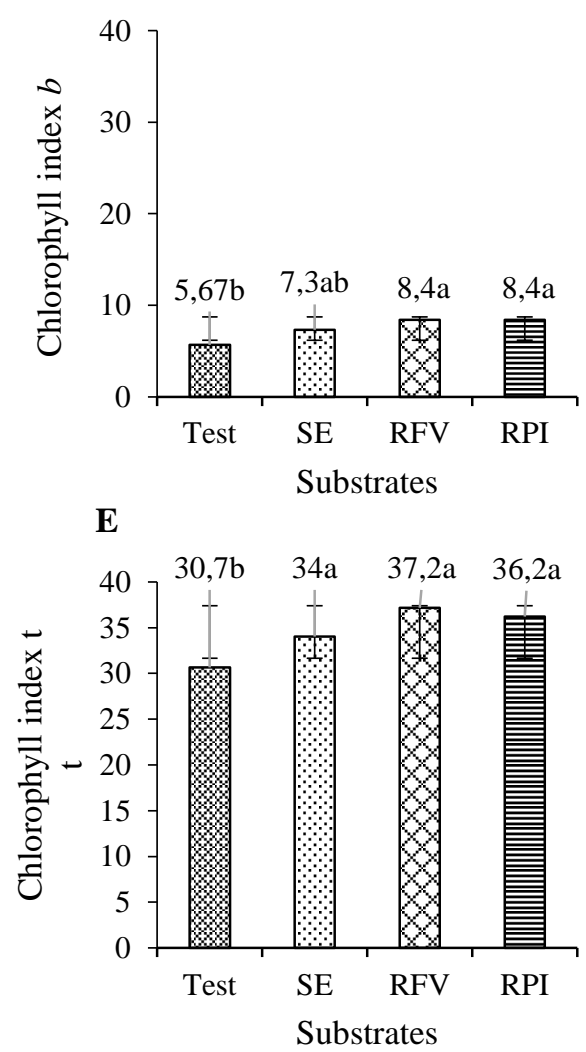

B
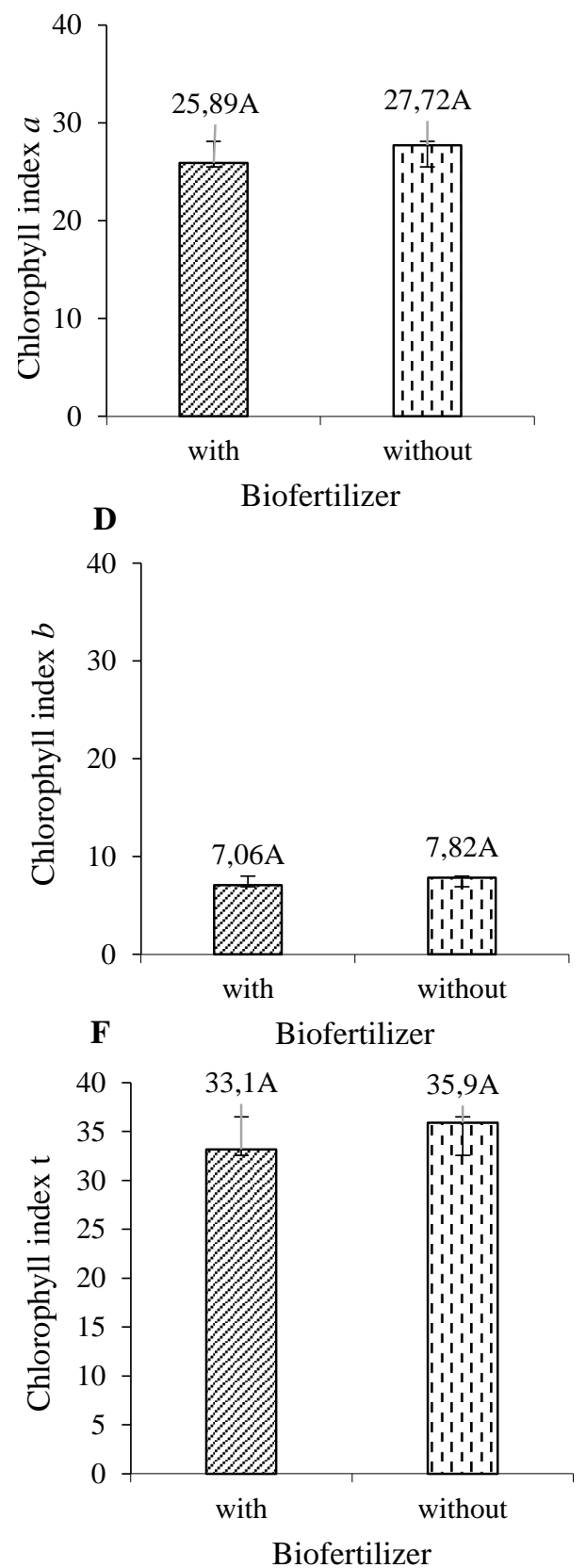

Figure 1. Chlorophyll index $a(A$ and $B), b(C$ and $D)$ and total chlorophyll $(E$ and $F)$ in function of the substrate (Test: control; SE: commercial compost; RFV: compost made with fruits and vegetables remains of the university restaurant; RPI: compost made with food remains of the university restaurant) and the application of biofertilizer in soil for Talisia esculenta seedlings. Means followed by the same lower case letter (substrates) and capital letter (presence and absence of biofertilizer) did not statistically differ by the Scott-Knott test $(p=0.05)$.

The stomatal conductance of $T$. esculenta seedlings was not different among treatments, regardless of the presence or the absence of a biofertilizer (Figure 2). Thus, potassium concentrations of the substrates provided a greater mechanical resistance on plant tissues, as an improvement on stomatal conductance $[3,15]$. Bearing in mind the functions of $\mathrm{K}$ in plants, by its increment in both regulation and turgidity of tissues, stomatal opening, closuring, and transpiration control, these are fundamental for increasing the water use efficiency by the plant Simonsson et al. (2016) [16], Nelson et al. (2005) [17] highlighted the existence of a direct relation between transpiration and stomatal conductance, considering a decrease in water vapor flow to the atmosphere and, consequently, the transpiration insofar the stomata close. 

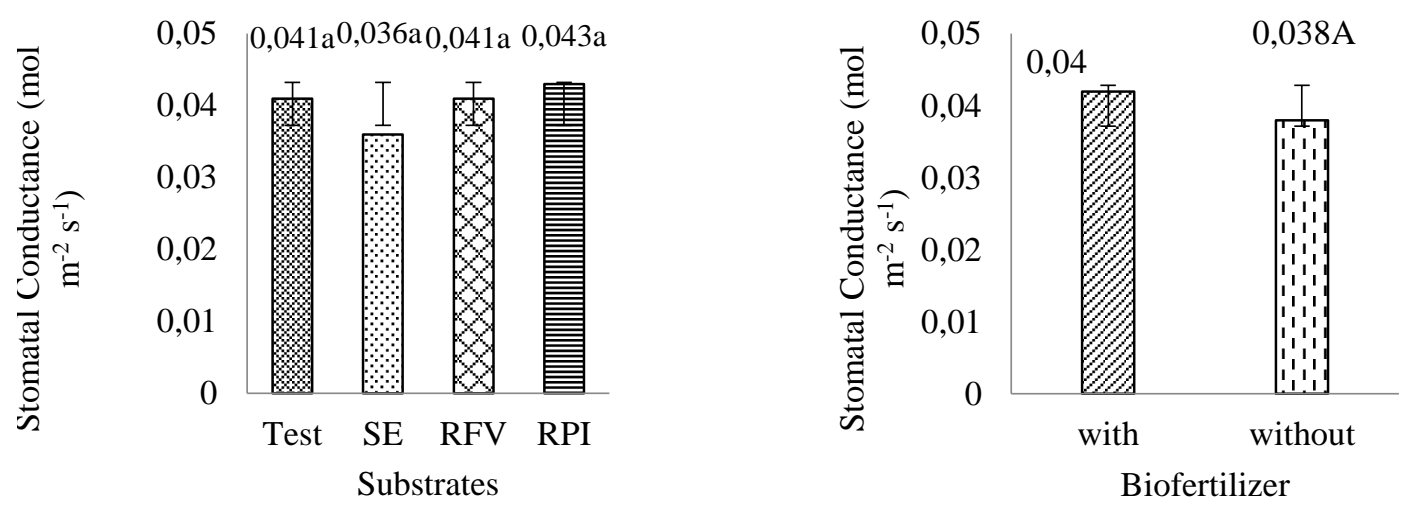

Figure 2. Stomatal conductance in function of the substrate (Test: control; SE: commercial compost; RFV: compost made with fruits and vegetables remains of the university restaurant; RPI: compost made with food remains of the university restaurant) and the application of biofertilizer in soil for Talisia esculenta seedlings. Means followed by the same lower case letter (substrates) and capital letter (presence and absence of biofertilizer) did not statistically differ by the Scott-Knott test $(p=0.05)$.

The transpiration rate of T. esculenta seedlings was increased with the addition of biofertilizer in the SE substrate. As for treatments without biofertilizer, no significant differences were verified, despite the fact that the interaction between substrate and biofertilizer increased seedlings transpiration and photosynthetic rate (Figure 3). Transpiration is related to the balanced concentration of potassium on the SE compost, indicating that with an adequate availability of K, plants can improve the control regarding water losses by transpiration, besides increasing this rate [18].

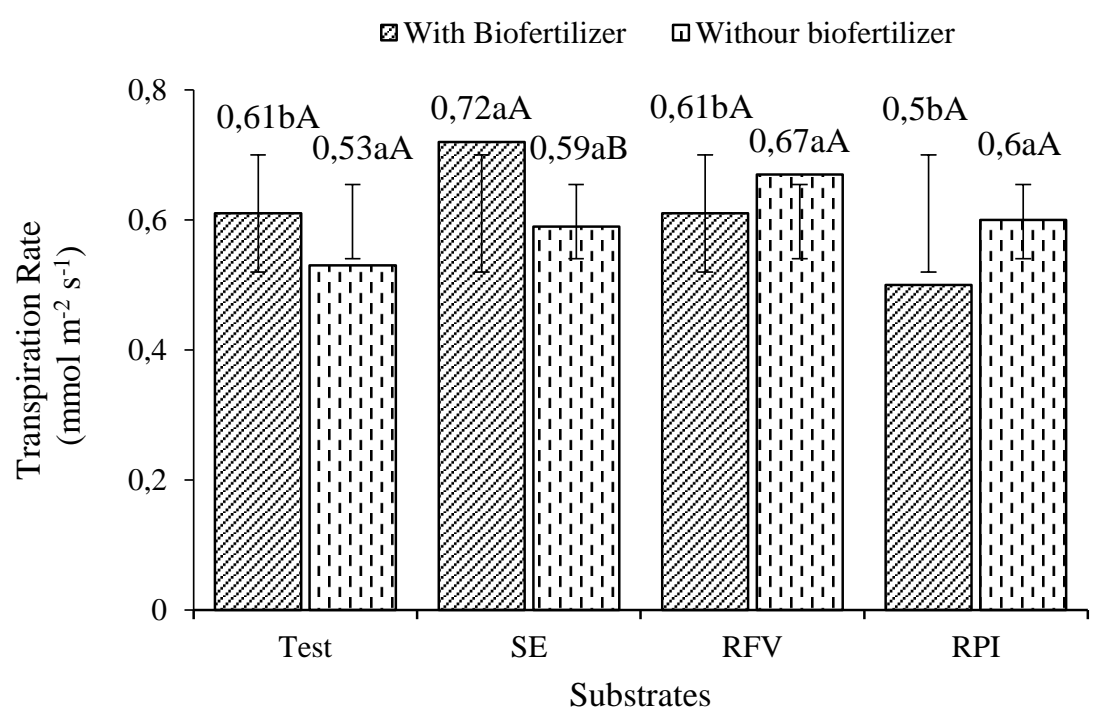

Figure 3. Transpiration rate in function of substrate (Test: control group; SE: commercial compost; RFV: compost made with fruits and vegetables remains of the university restaurant; RPI: compost made with food remains of the university restaurant) and the application of biofertilizer in soil for Talisia esculenta seedlings. Means followed by the same lower case letter (substrates) and capital letter (presence and absence of biofertilizer) did not statistically differ by the Scott-Knott test $(p=0.05)$.

When evaluating different substrates for collard greens seedling production, Lacerda et al. (2012) [19] observed that in plants cultivated in organic substrates constituted by coconut fibers, transpiration occurred in a higher frequency, when compared to bovine manure substrate Silva et al. (2011) [20] reported that the beneficial effects of bovine biofertilizer under transpiration result from the stimulus to the action of proteins and organic solutes, resulting in improved nutritional soil conditions and, in contrast, of the plants.

With the application of a biofertilizer, the formulated substrates RFV, RPI and the commercial substrate SE, were the ones that provided the highest photosynthetic rates. An increase of $47 \%$ of 
the photosynthetic rate was verified when using the biofertilizer on the SE substrate (Figure 4) As reported by Grulke et al. (2007) [21], photosynthesis is strongly related to stomatal opening and driven by the internal $\mathrm{CO}_{2}$ concentration, however no influences were observed on the treatments of this study.

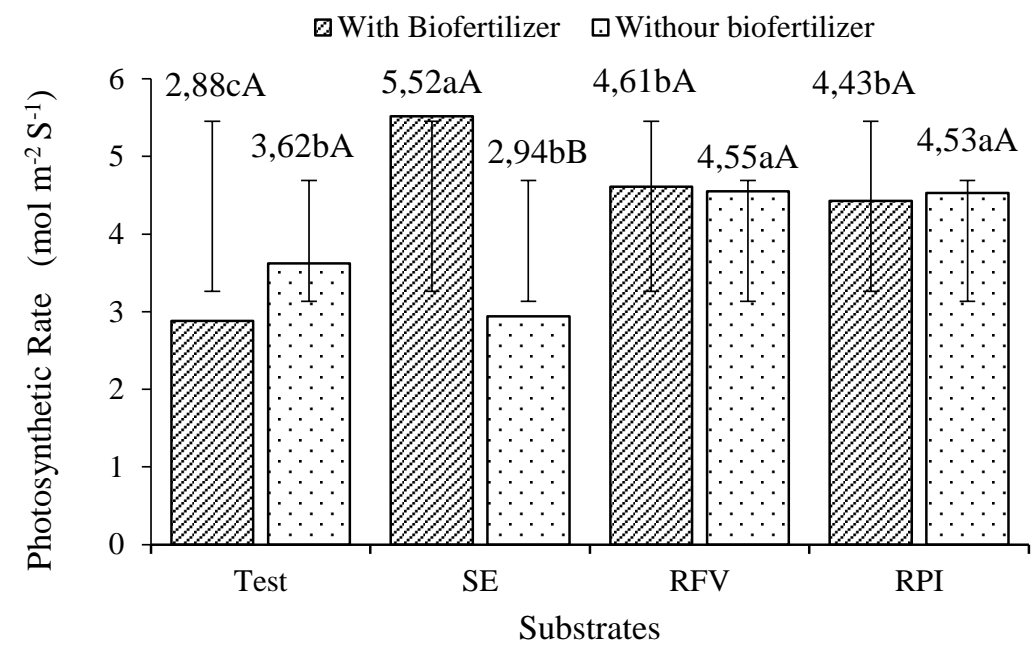

Figure 4. Photosynthetic rate in function of substrate (Test: control group; SE: commercial compost; RFV: compost made with fruits and vegetables remains of the university restaurant; RPI: compost made with food remains of the university restaurant) and the application of biofertilizer in soil for Talisia esculenta seedlings. Means followed by the same lower case letter (substrates) and capital letter (presence and absence of biofertilizer) did not statistically differ by the Scott-Knott test $(p=0.05)$.

Phosphorus is necessary to convert luminous into chemical energy (ATP) during photosynthesis [22]. As both the SE compost and the biofertilizer had elevated concentrations of these nutrients, it is possible that their interaction contributed to a greater increment on the photosynthetic rate.

The internal concentration of $\mathrm{CO} 2$ was not significant between the substrates used and the application of biofertilizer, however a higher concentration is observed in the substrates Test and RPI (Figure 5). Plants that are potentially nourished with potassium, displays greater water use efficiency and greater photosynthetic rates, due to the regular stomas opening, which leads to high carbon [23].
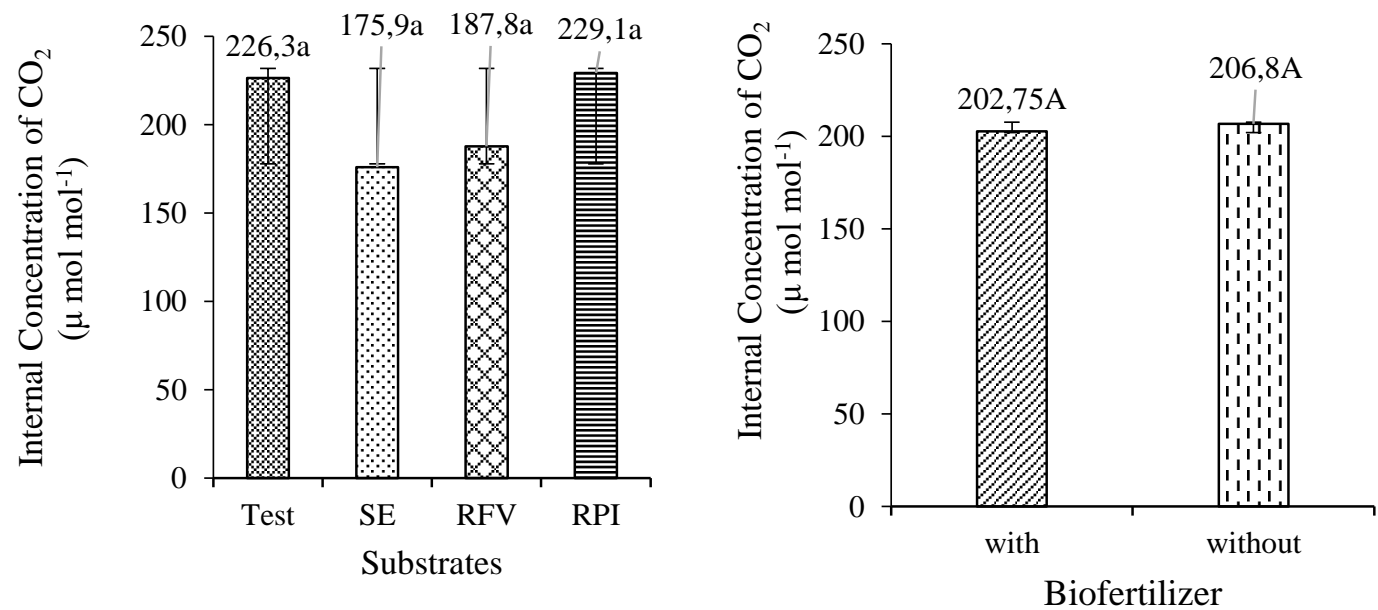

Figure 5. Internal concentration of carbon in function of substrate (Test: control; SE: commercial compost; RFV: compost made with fruits and vegetables remains of the university restaurant; RPI: compost made with food remains of the university restaurant) and the application of biofertilizer in soil for Talisia esculenta seedlings. Means followed by the same lower case letter (substrates) and capital letter (presence and absence of biofertilizer) did not statistically differ by the Scott-Knott test $(p=0.05)$. 
The test + biofertilizer and Se without biofertilizer treatments provided the lowest efficiency in the use of water by T. esculenta seedlings. Treatment the addition of biofertilizer did not significantly improved WUE (Figure 6).

It is important emphasize that $\mathrm{K}$ is a primary element to several plants' physiological actions, such as cellular turgor control, activation of enzymes involved in respiration, water relations, photosynthesis and adjustment of stomatal opening and closuring [24]. This nutrient also acts on the regulation of stomatal conductance mechanism, which controls the water use efficiency (increasing its efficacy), considering that the use of water molecules becomes more efficient [25]. This is why plants usually use mechanisms of adaptation in order to reduce transpiration, increase carboxylation efficiency and improve its water use [26].

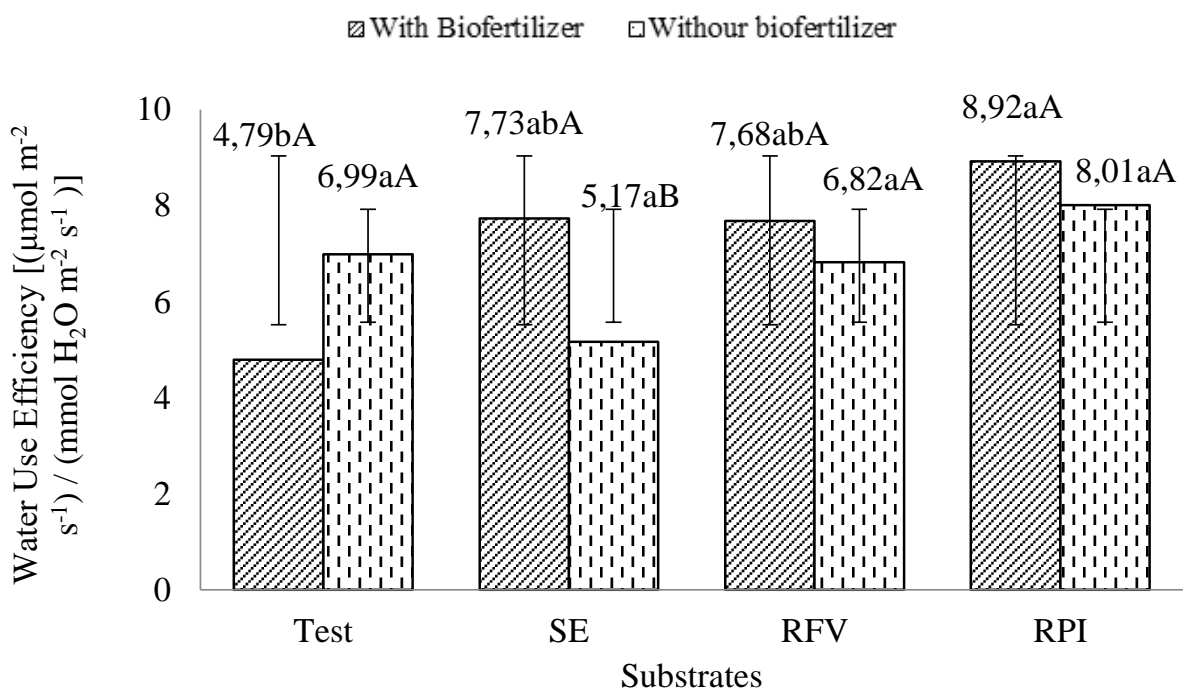

Figure 6. Water use efficiency in function of substrate (Test: control; SE: commercial compost; RFV: compost made with fruits and vegetables remains of the university restaurant; RPI: compost made with food remains of the university restaurant) and the application of biofertilizer in soil for Talisia esculenta seedlings. Means followed by the same lower case letter (substrates) and capital letter (presence and absence of biofertilizer) did not statistically differ by the Scott-Knott test $(p=0.05)$.

The treatment SE obtained a $63 \%$ increase in the instantaneous carboxylation efficiency due to the addition of biofertilizer on the substrate, when compared to the same substrate without biofertilizer. The substrates without biofertilizer were not significant (Figure 7). Santos et al. (2010) [27] reported significant results with lettuce (Lactuca sativa L.) subjected to composting with agro-industrial wastes, on substrates with a basic blend of sugarcane (Saccharum officinarum). 


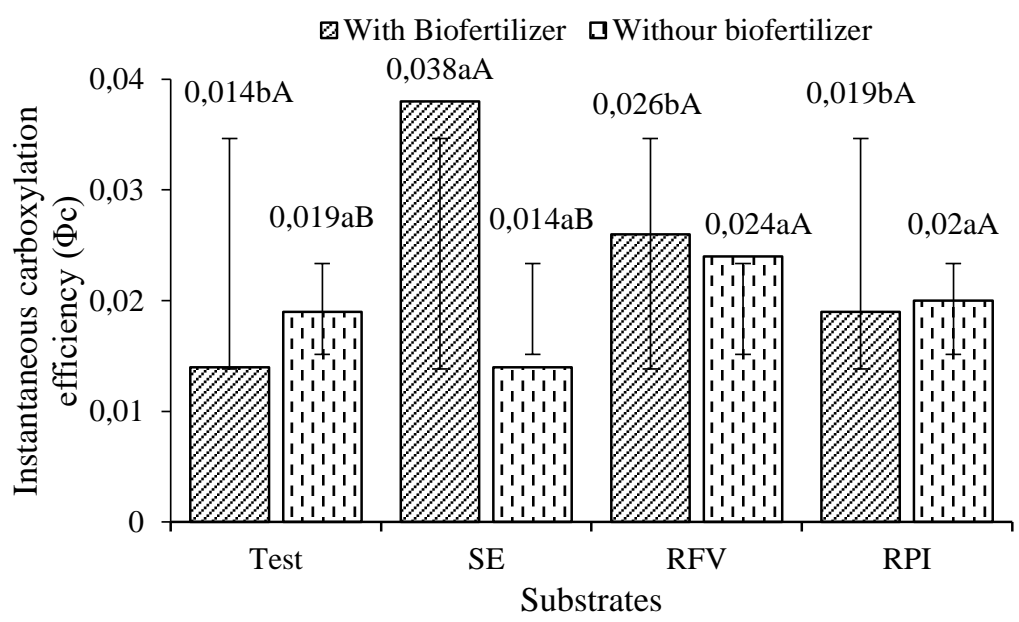

Figure 7. Instantaneous carboxylation efficiency in function of substrate (Test: control; SE: commercial compost; RFV: compost made with fruits and vegetables remains of the university restaurant; RPI: compost made with food remains of the university restaurant) and the application of biofertilizer in soil for Talisia esculenta seedlings. Means followed by the same lower case letter (substrates) and capital letter (presence and absence of biofertilizer) did not statistically differ by the Scott-Knott test $(p=0.05)$.

For Larcher (2006) [27], the instantaneous carboxylation efficiency is defined as the speed in which $\mathrm{CO}_{2}$ is fixed and processed. This fixation speed is mainly dependent both of the quantity of enzyme activity and the availability of $\mathrm{CO}_{2}$, which may be influenced by the acceptor concentration (Rubisco), temperature, hydration level of the protoplasm, mineral substances supply (especially phosphate), development degree and plant's activity. Considering that, both the SE substrate and the biofertilizer had high phosphorus levels, it may have provided a greater instantaneous carboxylation efficiency.

\section{CONCLUSION}

The substrates increases the chlorophyll a, b and total indices, except for the control substrate independent of the application of biofertilizer.

The efficiency of gas exchange increases with the addition of biofertilizer.

\section{REFERENCES}

1. Forza RC, Leitman PM, Costa A, Carvalho JRAA, Peixoto AL, Walter BMT, Zappi CBD, Costa D P, Lleras E, Martinelli G, Lima H, Prado J, Stehmann JR, Baumgratz JFA, Pirani JR, Sylvestre LS, Maia LC, Lohmann LG, Paganucci L, Silveira M, Nadruz M, Mamede MCH, Bastos MNC, Morim MP, Barbosa MR, Menezes M, Hopkins M, Secco R, Cavalcanti T, Souza VC. 2010. Catálogo de plantas e fungos do Brasil. Rio de Janeiro: Instituto de Pesquisa Jardim Botânico do Rio de Janeiro, 828 p.

2. Kohama S, Maluf AM, Bilia DAC, Barbedo CJ. Secagem e armazenamento de sementes de Eugenia brasiliensis Lam. (grumixameira). Rev Bras Sementes. 2006 Jan;28(1):72-78.

3. Tripler CE, KaushaL SS, Likens GE, Walter MT. Patterns in potassium dynamics in forest ecosystems. Ecol Letters. 2006 Mar;9(4):451-466. doi:10.1111/j.1461-0248.2006.00891.x

4. Wetzel MMVS, Borges JD, Venturoli F, Calil FN, Barreira S, Sette Junior CR Viveiros florestais: projeto, instalação, manejo e comercialização. Brasília: Semeando o bioma cerrado, 2011.31 p.

5. Amaral TL, Jasmim JM, Araújo JSP, Thiébaut JTL, Coelho F, Freitas CB. Adubação de orquídeas em substrato com fibra de coco. Ci Agrotecnol. 2010 Jan;34(1):11-19. doi:10.1590/S141370542010000100001

6. Lang DZ, Botrel MCG. Desenvolvimento de mudas de EucalyptusgrandisHill ex Maiden em diferentes substratos. Revista Cultivando o Saber. 2008 Jan:1(1):107-117.

7. Costa JRM. Viabilidade agroeconômica de genótipos de bananeira do tipo terra com resíduos orgânicos. 2008, 98f. Tese (Doutorado em Recursos naturais) - Universidade Federal de Campina Grande - Centro de Tecnologia e Recursos Naturais, Campina Grande. 
8. Falqueto AR, Cassol D, Magalhães Júnior AM, Oliveira AC, Bacarin MA. Crescimento e partição de assimilados em cultivares de arroz diferindo no potencial de produtividade de grãos. Bragantia. 2009 Set;68(3):563-571.

9. Fagan EB, Dourado Neto D, Vivian R, Franco RB, Yeda MP, Massignam LF, Oliveira RF, Martins KV. Efeito da aplicação de piraclostrobina na taxa fotossintética, respiração, atividade da enzima nitrato redutase e produtividade de grãos de soja. Bragantia. 2010 Dec;69(4):771-777.

10. Embrapa - Empresa Brasileira de Pesquisa Agropecuária. Solos: Sistema Brasileiro de Classificação de Solos. ed. Rio de Janeiro: Embrapa Solos, 2013. 353 p.

11. Penteado SR. Adubação Orgânica: Compostos orgânicos e biofertilizantes. (2 ed). Campinas, 2007.

12. Silva FASE, Azevedo CAV. Versão do programa computacional Assistat para o sistema operacional Windows. Rev Bras Produtos Agroind. 2002 Jan;4(1):71-78.

13. Engel VL, Poggiani F. Estudos da concentração de clorofila nas folhas e seu espectro de absorção de luz em função do sombreamento em mudas de quatro espécies florestais nativas. Rev Bras Fisiol Veg. $1991 \mathrm{Jan} ; 3(1): 39-45$.

14. Jesus SV, Marenco RA. O SPAD-502 como alternativa para a determinação dos teores de clorofila em espécies frutíferas. Acta Amazônica. 2008 Dec;38(4):815-818.

15. Simonsson M, Court M, Bergholm J, Lemarchand D, Hillier S. Mineralogy and biogeochemistry of potassium in the Skogaby experimental forest, southwest Sweden: pools, fluxes and $\mathrm{K} / \mathrm{Rb}$ ratios in soil and biomass. Biogeochemy. 2016 Dec;131(2):1-26.

16. Nelson KA, Motavalli PP, Nathan M. Response of No-Till Soybean [(L.) Merr.] to Timing of Preplant and Foliar Potassium Applications in a Claypan Soil. AgronJ. 2005 Sep;97(3):832-838. doi:10.2134/agronj2004.0241.

17. Gonçalves ER, Ferreira VM, Silva JV, Endres L, Barbosa TB, Duarte WG. Trocas gasosas e fluorescência da clorofila a em variedades de cana-de-açúcar submetidas à deficiência hídrica. Rev Bras Eng Agríc Amb. 2010 Abr;14(1):378-386.

18. Benlloch-Gonzáleza M, Quinterob JM, Suárezb MP, Sánchez-Lucasc R, Fernández-Escobara R, Benlloch M. Effect of moderate high temperature on the vegetative growth and potassium allocation in olive plants. J Plant Physiol. 2016 Dec;207(1):22-29. doi:10.1016/j.jplph.2016.10.001.

19. Lacerda FHD, Macedo ECF, Fortunato TCS, Medeiros E, Campos Junior JE. Substrato e concentração de nutrientes na solução nutritiva na produção de couve manteiga. Rev Verde Agroecol Desenv Sustent. 2012 Dec;7(4):51-58.

20. Silva FLB, Lacerda CF, Sousa GG, Neves ALR, Silva GL, Sousa CHC. Interação entre salinidade e biofertilizante bovino na cultura do feijão-de-corda. Rev Bras Eng Agríc Amb. 2011 Abr;15(4):383389. doi:10.1590/S1415-43662011000400009.

21. Grulke NE, Neufeld HS, Davison AW, Roberts M, Chapelka AH. Stomatal behavior of ozonesensitive and -insensitive coneflowers (Rudbeckia laciniata var. digitata) in Great Smoky Mountains Park. New Phytol. 2007 Sep;173:100-109,. doi:10.1111/j.1469-8137.2006.01872.x.

22. Prado RM, Natale W. Effect of Limingon the Mineral Nutrition and Yield of Growing Guava Trees in a Typic Hapludox Soil. Comm Soil Sci Plant Anal. 2008 Sep;39(3):2191-2204. doi:10.1080/00103620802137613.x.

23. Zorb C, Senbayram M, Peiter E. Potassium in Agriculture-Status and Perspectives. J Plant Physiol. 2014 May;171(9):656-669. doi:10.1016/j.jplph.2013.08.008.

24. Campos H, Trejo C, Peña-Valdivia CB, García-nava R, Conde-Martínez FV, Cruz-Ortega MR. Stomatal and non-stomatal limitations of bell pepper (Capsicum annuиm L.) plants under water stress and re-watering: Delayed restoration of photosynthesis during recovery. Environm Experim Bot. 2014 Fev;98(2):56-64. doi:10.1016/j.envexpbot.2013.10.015

25. Dutra WF, Melo AS, Dutra AF, Brito MEB, Filgueiras LMB, Meneses CHSG. Photosynthetic efficiency, gasex change and yield of castor bean inter cropped with peanut in semiarid Brazil. Rev Bras Eng Agríc Amb. 2017 Fev;21(2):106-110. doi:10.1590/1807-1929/agriambi.v21n2p106-110

26. Santos CM, Gonçalves ER, Endres L, Gomes TCA, Jadoski CJ, Nascimento LA, Santos ED. Atividade fotossintética em alface (Lactuca sativa L.) submetidas a diferentes compostagens de resíduos agroindustriais. Pesq Apl Agrotecnol. 2010 Sep;3(3):95-102.

27. Larcher W. Ecofisiologia vegetal. São Carlos: RIMA Artes e Textos, 2006. 532 p. 